\title{
PERAN KUALITAS PELAYANAN DAN KEPUASAN PELANGGAN DALAM PEMBENTUKAN WORD OF MOUTH MAHASISWA PERGURUAN TINGGI SWASTA DI JAKARTA
}

JURNAL

THE EFFECT OF SERVICE QUALITY AND CUSTOMER

MANAJEMEN

SATISFACTION TOWARDS ESTABLISHMENT ON HIGHER

INDONESIA

EDUCATION STUDENT WORD OF MOUTH IN PRIVATE COLLEGE JAKARTA

Vol.18 No.1

April 2018

Nani Fitriani

Institute Keuangan Perbankan dan Informatika Asia (ABFII) Perbanas Jakarta

nani.fitrie@perbanas.id

\begin{abstract}
Abstrak
Meningkatnya jumlah institusi penyedia jasa pendidikan tinggi membuat perguruan tinggi swasta harus menemukan dan menggunakan cara yang dapat menambah jumlah mahasiswa, diantaranya dengan meningkatkan kualitas pelayanan dan kepuasan pengguna jasa. Selain faktor kualitas pelayanan dan kepuasan pelanggan, seringkali keberadaan suatu produk juga diketahui masyarakat melalui informasi dari mulut ke mulut atau word of mouth (WOM). Penelitian ini mengukur peran kualitas pelayanan dan kepuasan pelanggan dalam pembentukan word of mouth (WOM). Instrumen yang digunakan untuk mengumpulkan data lapangan dalam penelitian ini adalah kuesioner tertulis. Sampel dalam penelitian ini adalah 150 orang mahasiswa Fakultas Ekonomi dan Bisnis di tiga perguruan tinggi swasta di Jakarta. Data primer yang diperoleh diolah menggunakan Structural Equation Modelling (SEM) dengan bantuan program komputer Analysis of Moment Structure (AMOS). Hasil penelitian ini membuktikan bahwa kualitas pelayanan memberikan pengaruh positif signifikan terhadap kepuasan pelanggan dengan koefisien pengaruh yang cukup tinggi yaitu 0,756. Hasil ini mengukuhkan temuan penelitian-penelitian sebelumnya. Namun, kualitas pelayanan tidak terbukti mempengaruhi WOM dengan koefisien sebesar 0,055 (sangat kecil sekali). Temuan ini menarik karena bertentangan dengan temuan-temuan sebelumnya yang menyatakan bahwa kualitas pelayanan mempengaruhi WOM. Hasil lain penelitian ini adalah kepuasan pelanggan mempengaruhi WOM, dengan koefisien sebesar 0,890. Dengan demikian, meningkatnya kepuasan mahasiswa akan berdampak pada meningkatnya aktifitas WOM.
\end{abstract}

Kata kunci: Pemasaran, Perguruan Tinggi, Kualitas Pelayanan, Kepuasan Pelanggan, Word of Mouth

\begin{abstract}
In the midst of increasing number of higher educational institutions, private universities must find and use certain ways that can increase the number of students. It can be done by improving service quality as well as customer satisfaction. In addition to service quality and customer satisfaction, often the existence of a product is also known by people through word of mouth (WOM). In WOM, people usually tell their experience of a product or service that they use without being asked. This study measures the role of service quality and customer satisfaction in word of mouth (WOM). The instrument used to collect field data in this study is a written questionnaire. The sample in this research is 150 students of Faculty of Economics and Business at three private universities in Jakarta. Primary data were processed using Structural Equation Modeling (SEM) with the help of computer program Analysis of Moment Structure (AMOS). The results of this study prove that the quality of service gives a significant positive effect on customer satisfaction with high coefficient that is 0.756 . This result supports the findings of previous studies. However, service quality is not proven to affect word of mouth, with a coefficient of 0.055 (very small). This finding is interesting as it contradicts previous findings which reveal that quality of service affects the word of mouth. Another result of this research is customer satisfaction affect word of mouth, with coefficient of 0.890. Thus,
\end{abstract}



mouth.

JURNAL

MANAJEMEN

INDONESIA

Vol.18 No.1

April 2018
Keywords: Marketing, Higher Education, Service Quality, Customer Satisfaction, Word of Mouth.

\section{Pendahuluan}

Pemahaman terhadap kebutuhan pengguna jasa sangat dibutuhkan oleh penyedia jasa pendidikan tinggi agar dapat bertahan di tengah-tengah persaingan yang semakin ketat. Karenanya, ada dua hal yang menjadi fokus pemenuhan kepuasan pelanggan, yakni bagaimana institusi pendidikan tinggi dapat memenuhi kebutuhan dan keinginan pengguna jasa, yaitu mahasiswa. Peningkatan kepuasan pelanggan dapat dilakukan dengan berbagai cara, di antaranya dengan lebih memperhatikan peningkatan kualitas pelayanan kepada pengguna jasa di perguruan tinggi.

Selain faktor kualitas pelayanan dan kepuasan pelanggan, seringkali keberadaan suatu produk juga diketahui masyarakat melalui informasi dari mulut ke mulut atau word of mouth. Kualitas pelayanan dikenal sebagai anteseden bagi kepuasan pelanggan (Taylor et al. 2004: 217-227). Sebagai antiseden, kualitas pelayanan merupakan prasyarat terpenuhinya kepuasan pelanggan. Pelanggan yang puas atas suatu produk atau jasa yang digunakannya akan menceritakan pengalaman yang ia alami kepada orang-orang yang ia kenal. Informasi dari mulut ke mulut (WOM) akan sampai dengan efektif kepada orang yang sedang memerlukan pertimbangan untuk membeli suatu produk atau menggunakan jasa tertentu. Adapun alasan orang lebih memilih mempercayai informasi dari mulut ke mulut adalah karena mereka lebih mengenal orang yang menyampaikan informasi. Namun demikian, terdapat perbedaan temuan (research gap) dari penelitian-penelitian terdahulu mengenai pengaruh antara variabelvariabel yang juga diteliti di dalam penelitian ini.

Dalam pemilihan perguruan tinggi, informasi dari mulut ke mulut juga merupakan hal yang penting untuk menjadi referensi oleh calon mahasiswa. Namun, mahasiswa akan melakukan tindakan WOM jika ia sudah merasakan kualitas pelayanan yang baik yang berdampak pada kepuasan. Karenanya, penelitian tentang hubungan antara kualitas pelayanan dan kepuasan pelanggan dalam pembentukan informasi dari mulut ke mulut pengguna jasa perguruan tinggi sangat penting untuk dilakukan.

\section{Kajian Literatur}

\subsection{Kualitas Pelayanan}

Kotler \& Keller (2012) mendefinisikan pelayanan sebagai "any intangible act or performance that one party offers to another that does not result in the ownership of anything". Dengan kata lain, pelayanan dapat didefinisikan sebagai penawaran atas jasa yang diberikan oleh satu pihak kepada pihak lain tanpa disertai kepemilikan. Menurutnya, kualitas adalah karakteristik barang atau jasa yang digunakan untuk memenuhi kebutuhan tertentu. Kualitas berkaitan erat dengan kebutuhan, karenanya kata kualitas menyiratkan adanya persyaratan tertentu sesuai dengan yang diharapkan pelanggan. Lovelock (2002: 5) mengemukakan bahwa pelayanan adalah kegiatan ekonomi yang menciptakan serta memberi manfaat kepada pelanggan pada saat-saat tertentu. Dengan kata lain, pelayanan adalah tindakan yang disesuaikan dengan kebutuhan pengguna jasa. Kotler (2003: 85) mendefinisikan pelayanan sebagai suatu aktifitas yang ditawarkan oleh satu pihak kepada pihak lain. Dengan demikian, orientasi utama pelayanan adalah adanya kepuasan pelanggan.

Dari definisi yang dikemukakan oleh beberapa pakar tersebut, dapat dikatakan bahwa kualitas pelayanan merupakan merupakan totalitas karakteristik sebuah pelayanan yang berorientasi pada pemenuhan kebutuhan pelanggan. Hal tersebut senada dengan yang dikemukakan oleh Parasuraman et al. (1985) yang mendefinisikan kualitas pelayanan sebagai "global evaluation or attitude of overall excellence of services". Evaluasi pelanggan atas suatu produk (baik barang maupun jasa) sangat menentukan apakah produk yang dipakai memiliki

Jurnal Manajemen Indonesia 
kualitas yang baik atau tidak. Parasuraman et al. (2002: 21) mengemukakan 5 dimensi kualitas pelayanan sebagai, yaitu Tangible, Reliability, Responsiveness, Assurance, dan Emphaty.

\subsection{Kepuasan Pelanggan}

Menurut Kotler (2003: 61) kepuasan adalah perasaan senang atau kecewa yang dirasakan oleh seseorang setelah membandingkan persepsi kinerja atau atau hasil suatu produk dengan harapannya. Jadi, di dalam kepuasan ada dua unsur besar yang dibandingkan, yaitu kinerja atau hasil suatu produk dan harapan pelanggan. Di sisi lain, harapan pelanggan juga dipengaruhi oleh beberapa faktor, seperti pengalaman, opini orang lain, serta janji-janji yang perusahaan. Zeithaml dan Bitner (2002) mengemukakan beberapa faktor yang mempengaruhi kepuasan pelanggan, yaitu fitur produk atau pelayanan, emosi pelanggan, atribusi keberhasilan atau kegagalan pelayanan, persepsi mengenai kewajaran dan keadilan, serta pengguna lain.

\subsection{Word Of Mouth (WOM)}

WOM didefinisikan sebagai komunikasi informal di kalangan masyarakat yang berisi tentang pengalaman atau kepuasan/ketidakpuasan seseorang atas produk atau jasa yang digunakan. Informasi ini disampaikan secara verbal (dari mulut ke mulut) dari satu orang ke orang yang lain sehingga menjadi rantai yang panjangnya tak terhingga. Para ahli dan pelaku pemasaran membagi WOM menjadi dua, yaitu buzz marketing dan viral marketing (Kotler \& Keller, 2012). Buzz marketing mendatangkan rasa senang, menciptakan publisitas, dan biasanya menghasilkan produk-produk lain yang berhubungan dengan produk yang akan dipasarkan. Di dalam buzz marketing, pemasar biasanya menciptakan kondisi agar produk atau jasa yang akan dijual menjadi perbincangan banyak orang. Viral marketing sering kali disebut word of mouth (WOM). Jutaan informasi tentang suatu produk akan tersebar dalam hitungan detik saat pemasar atau pengguna media sosial menekan tombol "share" atau "berbagi". Efektifitas pemasaran melalui WOM juga dikemukakan oleh Hart et al. (1990). Namun, para pakar ini menggarisbawahi bahwa tingkat kepuasan pelanggan sangat mempengaruhi WOM. Menurut penelitian yang mereka lakukan, satu pelanggan yang merasa tidak puas akan berbagi pengalamannya kepada 11 calon pelanggan, sedangkan seorang pelanggan yang merasa puas akan berbagi pengalamannya hanya kepada 6 orang pelanggan.

\subsection{Penelitian Terdahulu}

Li (2013) melakukan penelitian mengenai kualitas pelayanan, loyalitas pelanggan, dan word of mouth di beberapa perguruan tinggi swasta di Taiwan. Temuan dalam penelitiannya menunjukkan bahwa (1) Kualitas pelayanan memiliki pengaruh positif terhadap kepuasan pelanggan; (2) Kualitas pelayanan tidak berpengaruh terhadap loyalitas pelanggan; (3) Kepuasan pelanggan memiliki pengaruh positif terhadap loyalitas pelanggan; (4) Kualitas pelayanan tidak berpengaruh terhadap WOM; (5) Kepuasan pelanggan tidak terbukti mempengaruhi WOM; (6) Loyalitas pelanggan mempunyai pengaruh positif signifikan terhadap WOM.

Ada perbedaan (research gap) antara hasil penelitian Li dengan penelitian-penelitian mengenai word of mouth lainnya. Kazemi et al. (2013) meneliti hubungan antara loyalitas pelanggan dengan WOM dengan menggunakan kepuasan pelanggan dan brand commitment sebagai variabel mediasi. Penelitiannya dilakukan terhadap pelanggan Mellat Bank di Kermansah. Hasil penelitian Kazemi menunjukkan bahwa kepuasan pelanggan memiliki pengaruh yang signifikan terhadap WOM. Hal tersebut bertolak belakang dengan hasil penelitian yang dilakukan oleh $\mathrm{Li}$ yang menyatakan bahwa kepuasan pelanggan tidak mempengaruhi WOM.

Perbedaan temuan juga dipaparkan oleh Ha dan Hyunjoo (2012) yang meneliti pengaruh kualitas web design terhadap kepuasan pelanggan dan WOM dalam konteks belanja online. Hasil penelitian Ha dan Hyunjoo mengungkapkan bahwa kualitas informasi secara langsung mempengaruhi WOM. Selain itu, hasil penelitian para ahli ini juga mengungkapkan bahwa kepuasan pelanggan memiliki pengaruh positif signifikan terhadap WOM.

Lee, Ming Chan; Hwan, Ing Shan (2005) meneliti tentang hubungan antara kualitas pelayanan, kepuasan pelanggan, dan profitabilitas pada industri perbankan di Taiwan. 
Variabel yang diteliti dalam penelitian ini adalah profitabilitas sebagai variabel dependen, kepuasan dan minat beli sebagai variabel intervening, serta kualitas pelayanan sebagai variabel independen. Hasil penelitian mereka menunjukkan bahwa kualitas pelayanan berpengaruh signifikan terhadap kepuasan pelanggan. Ham (2003) dalam disertasi doktoralnya di Southern University menemukan hasil penelitian yang berbeda dengan penelitian-penelitian sebelumnya. Ham menelaah hubungan antara kualitas pelayanan, kepuasan pelanggan, dan perilaku pelanggan di perguruan tinggi. Variabel yang digunakan di dalam penelitian ini adalah perilaku pelanggan sebagai variabel dependen, kepuasan pelanggan sebagai variabel intervening, dan kualitas pelayanan sebagai variabel independen. Hasilnya menunjukan bahwa ada korelasi signifikan antara kualitas pelayanan dengan kepuasan pelanggan (mahasiswa).

Akbar et al. (2010) meneliti tentang pengaruh kualitas pelayanan terhadap kepuasan dan loyalitas pelanggan. Data penelitian dianalisis dengan menggunakan s-QUAL dan RecSQUAL. Penelitian ini juga menunjukkan bahwa kualitas pelayanan berpengaruh tidak langsung terhadap nilai pelanggan dan kepuasan pelanggan.

Penelitian lain dilakukan oleh Qin (2009) meneliti hubungan antara kualitas pelayanan yang diterima (perceived service quality), kepuasan pasien, dan kecenderungan perilaku (behavioral intentions) di Rumah Sakit Texas dalam disertasi doctoral di University of North Texas. Temuannya adalah kualitas pelayanan berpengaruh signifikan terhadap kepuasan pelanggan (pasien). Molinari et. al (2008) meneliti pengaruh kepuasan, kualitas, dan nilai pada pembelian ulang dan word of mouth dalam konteks B2B (business-to-business) pada perusahaan kargo di Amerika. Di dalam penjelasannya, Molinari memaparkan bahwa perusahaan lebih memilih harga yang murah sehingga mengesampingkan kualitas. Temuan lainnya di dalam penelitian mereka adalah kepuasan mempengaruhi word of mouth. Perusahaan yang merasa puas menggunakan perusahaan kargo tertentu akan menyebarkan informasi kepada perusahaan lain.

\subsection{Kerangka Pemikiran}

Kerangka pemikiran pada penelitian ini didasarkan kepada penelitian-penelitian terdahulu yang meneliti variabel-variabel yang sama yaitu, kualitas pelayanan, kepuasan pelanggan, loyalitas pelanggan, dan WOM. Penelitian-penelitian yang menjadi acuan untuk pembuatan model dalam penelitian ini adalah penelitian yang dilakukan oleh Li (2013), Kazemi et al. (2013), Ha \& Hyunjoo (2013), Taylor et al. (2004), Kasim \& Nor Asiah (2010), Lee \& Hwan (2005), Ham (2003), Akbar et al. (2010), Wen et al. (2012) dan Qin (2009). Kerangka pemikiran dalam penelitian ini dapat digambarkan di dalam model penelitian sebagai berikut.

Gambar 1

Kerangka Pemikiran

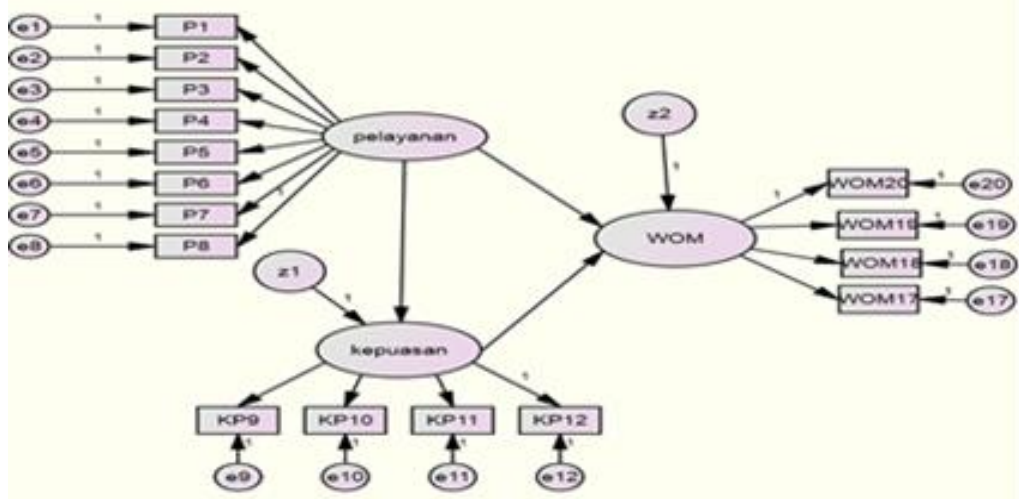

Jurnal Manajemen Indonesia 


\subsection{Hubungan antar Variabel}

\subsubsection{Pengaruh Kualitas Pelayanan Terhadap Kepuasan Pelanggan}

Penilaian atas kualitas pelayanan tidak dilakukan oleh penyedia layanan atau perusahaan, tetapi berdasarkan penilaian pelanggan yang sifatnya sangat relatif. Menurut Oliver dalam Wu (2006) penilaian terhadap kualitas pelayanan merupakan reaksi kognitif dan evaluatif terhadap atribut yang spesifik, sedangkan penilaian terhadap kepuasan lebih bersifat komprehensif, afektif, serta emosional.

Kualitas pelayanan dan kepuasan pelanggan merupakan variabel yang telah banyak diteliti di berbagai industri. Penelitian yang dilakukan oleh Li (2013), Kasim \& Nor Asiah (2010), Lee \& Hwan (2005), Ham (2003), Wen (2012), dan Qin (2009) menunjukkan bahwa kualitas pelayanan memiliki pengaruh terhadap kepuasan pelanggan. Dari temuan-temuan penelitian tersebut, dapat disimpulkan bahwa jika kualitas pelayanan baik, maka kepuasan pelanggan akan baik. Sebaliknya, jika kualitas pelayanan buruk, maka kepuasan pelanggan akan menurun. Berdasarkan uraian dan temuan penelitian-penelitian tersebut, hipotesis pertama dalam penelitian ini adalah:

\section{H1: Terdapat pengaruh kualitas pelayanan terhadap kepuasan pelanggan}

\subsubsection{Pengaruh Kualitas Pelayanan terhadap WOM}

Industri jasa merupakan industri yang secara alamiah menciptakan WOM. Harrison Walker (2001) mengungkapkan bahwa pelanggan memiliki kecenderungan untuk mencari referensi yang mereka percaya pada saat memilih jasa yang akan digunakan. Selain sebagai informasi penting, Harrison - Walker juga mengungkap bahwa WOM memiliki andil yang besar di dalam keputusan pembelian.

Pelanggan yang memiliki pengalaman atas suatu pelayanan akan menceritakan pengalamannya kepada orang lain. Karenanya, kualitas pelayanan dianggap memiliki pengaruh terhadap penyebaran informasi dari mulut ke mulut. Lebih jauh lagi, penelitian yang dilakukan oleh Harrison - Walker menggarisbawahi bahwa pelanggan akan lebih banyak melakukan WOM pada saat kualitas pelayanan rendah, hsil yang sama dikemukakan oleh Li (2013). Penelitian yang dilakukan oleh Ha \& Hyunjoo (2012) mengungkapkan adanya pengaruh kualitas pelayanan yang berupa kualitas informasi website terhadap WOM. Hal senada juga dikemukakan oleh $\mathrm{Ng}$ et al. (2011) yang meneliti hubungan antara aspek kualiatas pelayanan dengan WOM. Dalam temuannya, $\mathrm{Ng}$ et al. mengemukakan bahwa kualitas pelayanan fungsional (bagaimana pelayanan diberikan/delivered) memiliki pengaruh terhadap WOM. Namun, dalam temuan penelitian ini disebutkan bahwa kualitas pelayanan teknis (know-how and expertise of service provider) tidak mempengaruhi WOM. Walaupun ada perbedaan mengenai pengaruh kualitas pelayanan terhadap WOM, peneliti beranggapan bahwa sebagian hasil penelitian yang mengatakan bahwa ada pengaruh antara kualitas pelayanan terhadap WOM. Dengan kata lain, pelanggan yang merasakan kualitas pelayanan yang baik akan menyebarkan informasi dari mulut ke mulut dengan agresif. Sebaliknya, pelanggan yang merasa tidak puas, tidak akan menyebarkan informasi dari mulut ke mulut). Berdasarkan uraian tersebut, hipotesis kedua didalam penelitian ini dirumuskan sebagai berikut.

\section{H2: Terdapat pengaruh kualitas pelayanan terhadap WOM}

\subsubsection{Pengaruh Kepuasan Pelanggan Terhadap WOM}

Kepuasan pelanggan merupakan refleksi terpenuhinya harapan pelanggan atas kualitas pelayanan yang diterima. Pelanggan yang merasa puas akan berbagi pengalamannya dengan orang-orang yang ia kenal. Proses berbagi informasi secara informal ini akan menjurus kepada proses merekomendasikan. Penelitian-penelitian terdahulu membuktikan bahwa kepuasan pelanggan mempengaruhi WOM. Ranaweera dan Prabhu (2003) mengungkapkan bahwa kepuasan pelanggan dan kepercayaan merupakan dua faktor penting yang dapat menciptakan WOM. Penelitian lain yang mengungkapkan adanya pengaruh kepusan pelanggan terhadap 
WOM adalah penelitian yang dilakukan oleh Kazemi et. al (2013) pada nasabah Bank Melat di Kermanshah. Dari hasil penelitian terdahulu dinyatakan bahwa ada hubungan antara kepuasan pelanggan dengan WOM. Dengan kata lain, pelanggan yang merasa puas akan berpengaruh terhadap kegiatan word of mouth. Sebaliknya, pelanggan yang tidak puas, tidak akan mempengaruhi word of mouth. Berdasarkan hasil penelitian-penelitian terdahulu, hipotesis ketiga di dalam penelitian ini adalah sebagai berikut.

\section{H3: Terdapat pengaruh kepuasan pelanggan terhadap WOM}

\section{Metode Penelitian}

\subsection{Desain Penelitian}

Rancangan yang digunakan dalam penelitian ini adalah ancangan kuantitatif (quantitative-hypothesis testing research), yaitu penelitian yang dilakukan melalui sebuah proses yang memungkinkan peneliti membangun hipotesis dan mengujinya secara empirik (Ferdinad, 2014: 9).

\subsection{Populasi dan Sampel Penelitian}

Populasi dalam penelitian ini adalah mahasiswa perguruan tinggi swasta di Jakarta. Sampel dalam penelitian ini adalah 150 orang mahasiswa Fakultas Ekonomi di tiga perguruan tinggi swasta di Jakarta. Pada awalnya, kuesioner yang didistribusikan berjumlah 300 kuesioner. Dari 300 kuesioner tersebut, kembali ke peneliti sejumlah 256 kuesioner. Selanjutnya dilakukan uji normalitas data untuk mengeluarkan outliers sehingga data berdistribusi normal. Uji terhadap outliers multivariat dilakukan dengan menggunakan kriteria jarak mahalanobis pada tingkat $\mathrm{p}<0,001$. Hasil uji normalitas data menunjukkan bahwa hanya ada 150 data yang dapat digunakan sebagai sampel dalam penelitian ini.

\subsection{Data dan Sumber Data}

Penelitian ini menggunakan data primer. Data diperoleh dari 150 mahasiswa Fakultas Ekonomi di perguruan tinggi swasta di Jakarta.

\subsection{Teknik Pengumpulan Data}

Pendekatan yang digunakan dalam pemilihan sampel adalah non-probability sampling dengan teknik purposive sampling.

\subsection{Instrumen Penelitian}

Instrumen yang digunakan untuk mengumpulkan data lapangan dalam penelitian ini adalah kuesioner tertulis. Skala pengukuran yang digunakan adalah skala interval (1-10), angka 1 berarti "sangat tidak setuju", angka 10 menunjukkan "sangat setuju".

\section{Tabel 1}

Kisi-kisi penelitian yang berpengaruh kepada kualitas pelayanan

\begin{tabular}{|c|c|c|c|c|c|c|}
\hline Variabel & $\begin{array}{c}\text { Konsep } \\
\text { Variabel } \\
\end{array}$ & Dimensi & Indikator & $\begin{array}{c}\text { No } \\
\text { Butir }\end{array}$ & $\begin{array}{l}\text { Jml } \\
\text { Butir }\end{array}$ & Skala \\
\hline \multirow{3}{*}{$\begin{array}{l}\text { Kualitas } \\
\text { Pelayanan } \\
\text { (P) }\end{array}$} & \multirow{3}{*}{$\begin{array}{l}\text { totalitas } \\
\text { karakteristik } \\
\text { sebuah } \\
\text { pelayanan } \\
\text { yang } \\
\text { berorientasi } \\
\text { pada } \\
\text { pemenuhan } \\
\text { kebutuhan }\end{array}$} & \multirow[b]{2}{*}{ Tangibles } & $\begin{array}{c}\text { Penampilan } \\
\text { fisik gedung } \\
\text { menarik }\end{array}$ & 1 & \multirow{3}{*}{ 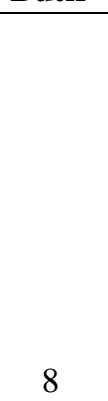 } & interval \\
\hline & & & $\begin{array}{c}\text { Fasilitas } \\
\text { belajar } \\
\text { mengajar } \\
\text { modern }\end{array}$ & 2 & & interval \\
\hline & & Reliability & $\begin{array}{l}\text { Pelayanan } \\
\text { tepat waktu }\end{array}$ & 3 & & interval \\
\hline
\end{tabular}

Jurnal Manajemen Indonesia 


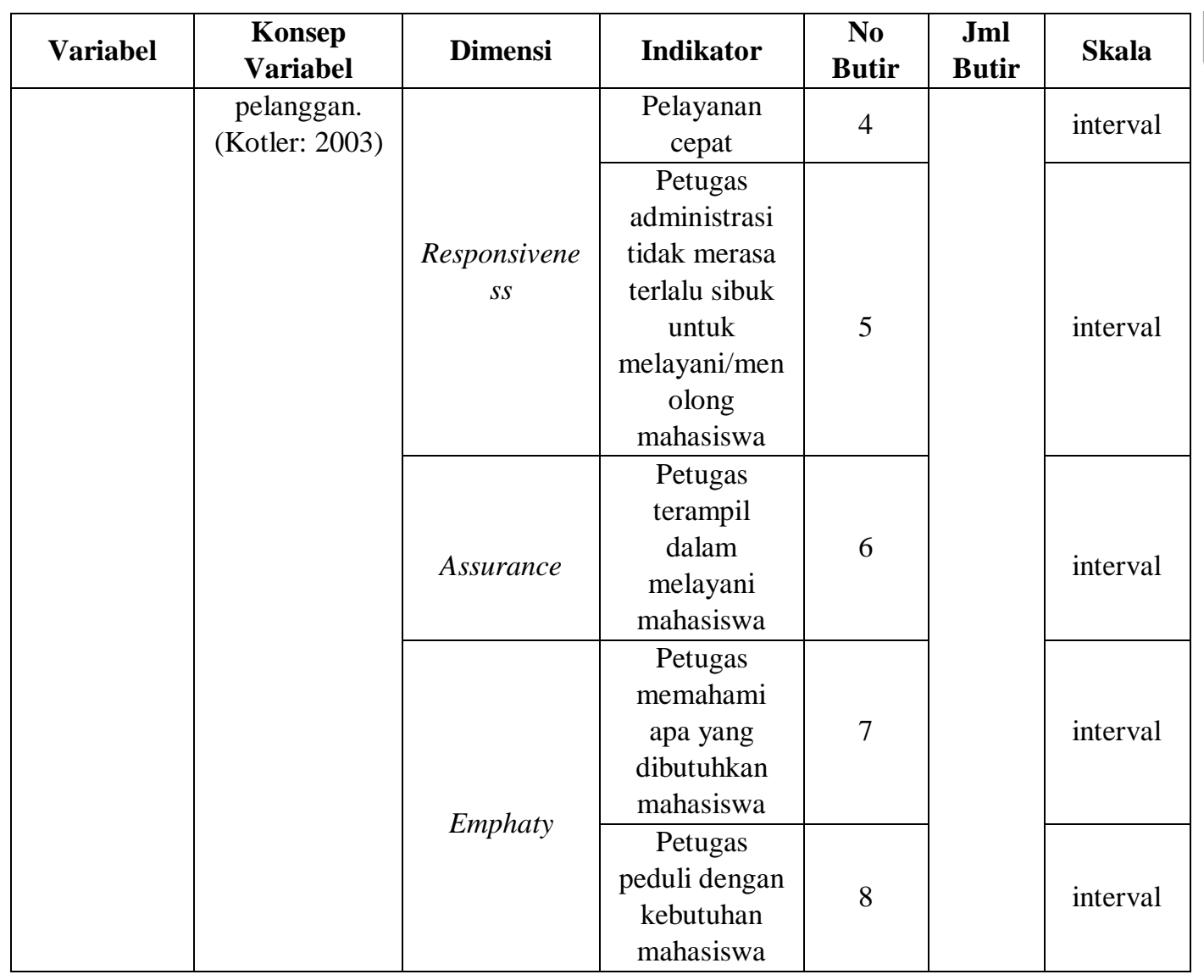

JURNAL

MANAJEMEN

INDONESIA

Vol.18 No.1

April 2018

Tabel 2

Kisi-kisi

penelitian yang

berpengaruh

kepada kepuasan

pelanggan

\begin{tabular}{|c|c|c|c|c|c|}
\hline Variabel & Konsep Variabel & Indikator & No Butir & $\begin{array}{c}\text { Jml } \\
\text { Butir }\end{array}$ & Skala \\
\hline \multirow{4}{*}{$\begin{array}{l}\text { Kepuasan } \\
\text { Pelanggan }\end{array}$} & \multirow{4}{*}{$\begin{array}{c}\text { Kepuasan pelanggan } \\
\text { atau customer } \\
\text { satisfaction adalah } \\
\text { perasaan senang atau } \\
\text { kecewa yang } \\
\text { dirasakan oleh } \\
\text { seseorang setelah ia } \\
\text { membandingkan } \\
\text { persepsi kinerja atau } \\
\text { atau hasil suatu } \\
\text { produk dengan } \\
\text { harapannya (Kotler: } \\
\text { 2003). }\end{array}$} & $\begin{array}{c}\text { Pelayanan yang } \\
\text { diberikan oleh } \\
\text { kampus sesuai } \\
\text { dengan harapan saya }\end{array}$ & 9 & \multirow{4}{*}{4} & interval \\
\hline & & $\begin{array}{l}\text { Kehandalan yang } \\
\text { diberikan oleh } \\
\text { karyawan kampus } \\
\text { dalam melayani } \\
\text { mahasiswa sesuai } \\
\text { dengan harapan } \\
\text { saya. } \\
\end{array}$ & 10 & & \\
\hline & & $\begin{array}{c}\text { Fasilitas yang } \\
\text { disediakan sesuai } \\
\text { dengan harapan } \\
\text { saya. }\end{array}$ & 11 & & \\
\hline & & $\begin{array}{l}\text { Saya merasa puas } \\
\text { belajar di kampus } \\
\text { ini. }\end{array}$ & 12 & & interval \\
\hline
\end{tabular}




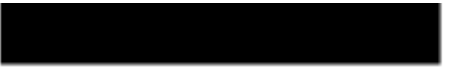

JURNAL

MANAJEMEN

INDONESIA

Vol.18 No.1

April 2018

Tabel 3

Kisi-kisi penelitian yang berpengaruh kepada word of mouth

\begin{tabular}{|c|c|c|c|c|c|}
\hline Variabel & $\begin{array}{c}\text { Konsep } \\
\text { Variabel }\end{array}$ & Indikator & $\begin{array}{c}\text { No } \\
\text { Butir }\end{array}$ & $\begin{array}{c}\text { Jml } \\
\text { Butir }\end{array}$ & Skala \\
\hline \multirow{4}{*}{$\begin{array}{c}\text { Word of } \\
\text { mouth }\end{array}$} & \multirow{4}{*}{$\begin{array}{c}\text { Word of Mouth } \\
\text { (WOM) } \\
\text { didefinisikan } \\
\text { sebagai } \\
\text { komunikasi } \\
\text { informal di } \\
\text { kalangan } \\
\text { masyarakat } \\
\text { yang berisi } \\
\text { tentang } \\
\text { pengalaman } \\
\text { atau } \\
\text { kepuasan/ketida } \\
\text { kpuasan } \\
\text { seseorang atas } \\
\text { produk atau jasa } \\
\text { yang ia } \\
\text { gunakan. } \\
\text { Informasi ini } \\
\text { disampaikan } \\
\text { secara verbal } \\
\text { (dari mulut ke } \\
\text { mulut) dari satu } \\
\text { orang ke orang } \\
\text { yang lain } \\
\text { (Kotler \& } \\
\text { Keller, 2012). }\end{array}$} & $\begin{array}{c}\text { Mahasiswa menceritakan } \\
\text { keunggulan-keunggulan } \\
\text { kampus kepada teman- } \\
\text { teman di luar kampus }\end{array}$ & 13 & \multirow[b]{4}{*}{4} & interval \\
\hline & & $\begin{array}{c}\text { Mahasiswa menceritakan } \\
\text { kepada orang lain bahwa } \\
\text { ia senang belajar di } \\
\text { kampusnya saat ini }\end{array}$ & 14 & & interval \\
\hline & & $\begin{array}{c}\text { Mahasiswa suka } \\
\text { menceritakan kebaikan } \\
\text { kampusnya secara rinci } \\
\text { kepada orang lain }\end{array}$ & 15 & & interval \\
\hline & & $\begin{array}{l}\text { Mahasiswa ingin orang } \\
\text { lain tahu bahwa ia bangga } \\
\text { sebagai mahasiswa di } \\
\text { kampusnya saat ini }\end{array}$ & 16 & & interval \\
\hline
\end{tabular}

\subsection{Tahapan Analisis SEM}

Data primer yang diperoleh diolah menggunakan Structural Equation Modelling (SEM) dengan bantuan program komputer Analysis of Moment Structure (AMOS). Uji validitas dan reliabilitas instrumen menunjukkan bahwa semua variabel valid dan reliabel. Hal ini dibuktikan dengan tingginya Cronbach's Alpha, yakni 0,914 untuk variabel kualitas pelayanan, 0,793 untuk variabel kepuasan pelanggan, dan 0,929 untuk variabel word of mouth. Selanjutnya, dilakukan uji outliers, multikolinearitas, serta evaluasi kriteria goodness of fit.

\section{Hasil dan Pembahasan}

\subsection{Uji konfirmatory konstruk Kualitas Pelayanan, Kepuasan Pelanggan, dan Word of Mouth dengan Confirmatory Factor Analysis (CFA) full model}

Berikut ini adalah gambar full model persamaan struktural penelitian dengan menggunakan AMOS versi 18.0.

Jurnal Manajemen Indonesia 


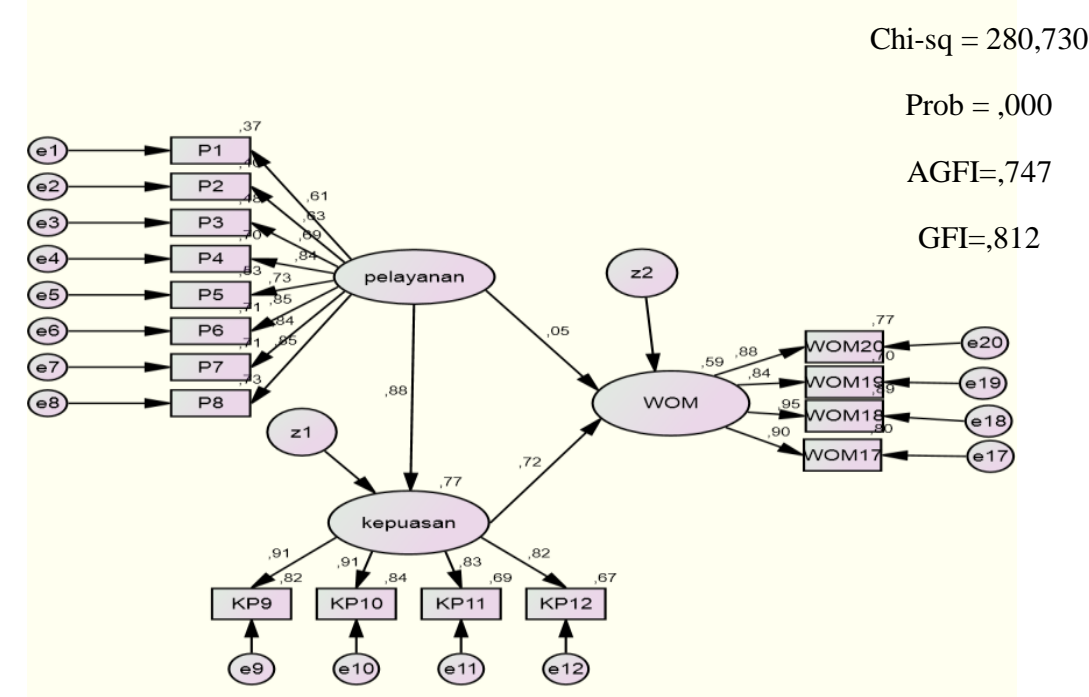

Model persamaan struktural di dalam penelitian ini secara keseluruhan telah memenuhi kriteria fit. Meskipun nilai RMSEA $(0,109)$ dan probabilitas tidak terpenuhi $(0,000)$, nilai chisquare minimum untuk data yang ada, yaitu 280,730 adalah baik. Selain itu, nilai GFI $(0,812)$, AGFI $(0,747)$, NFI $(0,872)$, dan TLI $(0,900)$ mendekati marjinal. Nilai CMIN/DF dalam penelitian ini sebesar 2,780 menunjukkan bahwa model fit.

Nilai $X^{2}$ - Chi Square dalam penelitian ini adalah 280,730 dengan probability index 0,000. Nilai RMSEA untuk data dalam penelitian ini adalah ,109. Angka CMIN/DF sebesar 2,780 menunjukkan bahwa model dalam penelitian ini dapat diterima (Ferdinand, 2014). Ghazali (2013) menyebutkan bahwa nilai CMIN/DF dibawah 5 sebagai nilai yang reasonable atau dapat diterima. Selain itu, nilai GFI, AGFI, TLI, dan NFI menunjukkan tingkatan marjinal sebuah model. Dengan demikian, secara keseluruhan model dapat diterima.

\subsection{Pengujian Hipotesis}

\begin{tabular}{|c|c|c|c|c|c|}
\hline Hipotesis & Path & t-value & P & CR & Kesimpulan \\
\hline H1 & $\mathrm{P} \rightarrow \mathrm{KP}$ & 0,878 & 0,000 & 10,644 & Diterima \\
\hline H3 & $\mathrm{P} \rightarrow \mathrm{WOM}$ & 0,052 & 0,738 & 0,334 & Ditolak \\
\hline $\mathrm{H} 5$ & $\mathrm{KP} \rightarrow \mathrm{WOM}$ & 0,720 & 0,000 & 4,451 & Diterima \\
\hline
\end{tabular}

\subsection{Pengaruh Variabel Kualitas Pelayanan Terhadap Kepuasan Pelanggan}

Dari hasil analisis SEM, diketahui besarnya pengaruh langsung variabel kualitas pelayanan terhadap kepuasan pelanggan adalah 0,878 dengan nilai critical ratio (CR) sebesar 10,644 dan probabilitas (P) sebesar 0,000. Dari tabel 4, dapat kita lihat bahwa variabel kualitas pelayanan berpengaruh terhadap variabel kepuasan pelanggan karena nilai $\mathrm{CR}> \pm 1,96$ dan nilai $\mathrm{P}<0,005$. Besarnya pengaruh koefisien langsung antara variabel kualitas pelayanan terhadap kepuasan pelanggan adalah 0,756 . Koefisien ini menunjukkan bahwa ada pengaruh positif variabel kualitas pelayanan terhadap kepuasan pelanggan. Dengan kata lain kualitas pelayanan yang baik akan berdampak pada baiknya kepuasan pelanggan. Implikasi dari temuan ini adalah lembaga pendidikan tinggi swasta harus dapat menemukan cara-cara baru
JURNAL

MANAJEMEN

INDONESIA

Vol.18 No.1

April 2018

Gambar 2

Uji konfirmatory konstruk Kualitas

Pelayanan,

Kepuasan

Pelanggan, dan

Word of Mouth dengan

Confirmatory

Factor Analysis

(CFA) full model

(Sumber: data primer yang diolah,

2016)

Tabel 4.

Hasil Uji Hipotesis Penelitian 
untuk dapat meningkatkan kepuasan pelanggan. Cara itu dapat diperoleh melaui analisa kebutuhan pelanggan yang sudah ada atau kepada calon pelanggan.

JURNAL

MANAJEMEN

INDONESIA

Vol.18 No.1

April 2018

\subsection{Pengaruh Variabel Kualitas Pelayanan Terhadap Word of Mouth}

Besarnya pengaruh langsung variabel kualitas pelayanan terhadap word of mouth adalah 0,052 dengan nilai critical ratio (CR) sebesar 0,334 dan probabilitas (P) sebesar 0,738. Besarnya pengaruh koefisien langsung antara variabel kualitas pelayanan terhadap kepuasan pelanggan adalah 0,55 Koefisien ini menunjukkan bahwa peningkatan kualitas pelayanan tidak menyebabkan meningkatnya word of mouth yang dilakukan oleh pelanggan. Dengan kata lain, peningkatan kualitas pelayanan tidak meningkatkan aktifitas menyebarkan informasi dari mulut ke mulut atau bercerita kepada orang lain. Temuan ini menarik, karena bertentangan dengan sebagian besar temuan dari penelitian-penelitian sebelumnya yang menyatakan bahwa variabel kualitas pelayanan berpengaruh langsung terhadap word of mouth. Dengan kata lain, baik buruknya kualitas pelayanan tidak mempengaruhi proses penyebaran informasi dari mulut ke mulut. Namun demikian, sebaiknya penyedia jasa pendidikan tinggi tetap tidak mengabaikan kualitas pelayanan terhadap pelanggan agar WOM yang dilakukan pelanggan adalah WOM positif.

\subsection{Pengaruh Variabel Kepuasan Pelanggan Terhadap Word of Mouth}

Besarnya pengaruh langsung variabel kepuasan pelanggan terhadap word of mouth adalah 0,720 dengan nilai critical ratio (CR) sebesar 4,451 dan probabilitas $(\mathrm{P})$ sebesar 0,000 . Hasil tersebut menunjukkan bahwa variabel kepuasan pelanggan berpengaruh terhadap variabel word of mouth karena nilai $\mathrm{CR}> \pm 1,96$ dan nilai $\mathrm{P}<0,005$. Besarnya pengaruh koefisien langsung antara variabel kepuasan pelanggan terhadap WOM pelanggan adalah 0,890. Koefisien ini menunjukkan bahwa ada pengaruh positif variabel kepuasan pelanggan terhadap word of mouth. Karenanya, dapat dikatakan bahwa meningkatnya kepuasan pelanggan akan berdampak pada peningkatan word of mouth. Implikasi dari temuan ini adalah lembaga pendidikan tinggi harus selalu berupaya meningkatkan kepuasan pelanggan. Jika tidak, maka akan menghambat proses penyebaran informasi dari mulut ke mulut.

\section{Kesimpulan dan Saran}

Hasil penelitian ini membuktikan bahwa kualitas pelayanan memberikan pengaruh positif signifikan terhadap kepuasan pelanggan. Dari hasil uji konfirmatori konstruk variabel kualitas pelayanan dan kepuasan pelanggan terlihat bahwa koefisien pengaruh langsung variabel kualitas pelayanan terhadap kepuasan pelanggan cukup tinggi, yaitu 0,756. Ini berarti bahwa semaikin baik kualitas pelayanan menyebabkan meningkatnya kepuasan mahasiswa. Hal lain yang dapat disimpulkan di dalam penelitian ini adalah kualitas pelayanan tidak mempengaruhi word of mouth. Hal ini dikuatkan dengan bukti uji konfirmatori konstruk yang menunjukkan bahwa koefisien pengaruh langsung variabel kualitas pelayanan terhadap word of mouth sebesar 0,055 (sangat kecil sekali). Walaupun secara umum mahasiswa menilai kualitas pelayanan yang diberikan oleh kampusnya sudah cukup baik, mereka tidak serta merta melakukan kegiatan penyebaran informasi melalui word of mouth.

Temuan yang menarik dari penelitian ini adalah, beberapa responden yang menyatakan mereka tidak puas dengan pelayanan memberikan indikasi melakukan aktifitas penyebaran informasi dari mulut ke mulut (word of mouth). Kesimpulan lainnya di dalam penelitian ini adalah kepuasan pelanggan mempengaruhi word of mouth. Hasil uji konfirmatori konstruk menunjukkan bahwa koefisien pengaruh langsung antara kepuasan pelanggan dan word of mouth memiliki nilai positif dan signifikan, yaitu 0,890 . Dengan demikian, meningkatnya kepuasan mahasiswa akan berdampak pada meningkatnya aktifitas word of mouth. Karenanya, perlu ada upaya terus menerus untuk meningkatkan kepuasan mahasiswa agar terjadi peningkatan word of mouth.

Karena dalam penelitian ini kualitas pelayanan tidak terbukti berpengaruh terhadap word of mouth, untuk penelitian-penelitian berikutnya yang terkait dengan pemasaran di perguruan tinggi, khususnya perguruan tinggi swasta, agar memunculkan faktor-faktor lain yang mungkin berpengaruh langsung dalam pembentukan word of mouth, misalnya strategi 
penetapan harga dan strategi komunikasi pemasaran berbasis teknologi. Hal ini akan memberikan lebih banyak kemungkinan kepada perguruan-perguruan tinggi swasta untuk dapat bertahan di sela-sela persaingan yang semakin ketat melaui peningkatan word of mouth.

\section{Daftar Pustaka}

Akbar, S., Som, A. P. M., Wadood, F., \& Alzaidiyeen, N. J. (2010). Revitalization of service quality to gain customer satisfaction and loyalty. International Journal of Business and Management, 5(6), 113.

Ferdinand, A. (2002). Structural equation modeling dalam penelitian manajemen. Semarang: Badan Penerbit Universitas Diponegoro.

Ghozali, I. (2013). Model Persamaan Struktural Konsep dan Aplikasi dengan Program AMOS 21.0. Semarang: Badan Penerbit Universitas Diponegoro.

Ha, Y., \& Im, H. (2012). Role of web site design quality in satisfaction and word of mouth generation. Journal of Service Management, 23(1), 79-96.

Ham, C. L. (2003). Service Quality, Customer Satisfaction, and Customer Behavioral Intention in Higher Education. Southern University. Doctoral Dissertation.

Harrison - Walker, L. Jean. (2001). The Measurement of Word of Mouth Communication and an Investigation of Service Quality and Customer Commitment as Potential Anticedents. Journal of Service Research: JSR, 4(1): 60-75.

Hart, C. W., Heskett, J. L., \& Sasser, J. W. (1990). The profitable art of service recovery. Harvard business review, 68(4), 148-156.

Kazemi, A., Paemami, V., Abbaszadeh, A., Pourzamani, J. (2013). Impact of Brand Identity on Customer Loyalty and Word of Mouth Communications, Considering Mediating Role of Customer Satisfaction and Brand Commitment (Case Study: Customers of Mellat Bank in Kermansah). International Journal of Academic Research in Economics and Management Sciences, 2(4): 1-14.

Kotler, P. (2003). Marketing Management, 11th Edition. New Jersey: Prentice Hall Inc.

Kotler, P. \& Keller, K.L. (2012). Marketing Management 14th Edition. New Jersey: Pearson Education.

Lee, M.C. \& Hwan, I.S. (2005). Relationship among Service Quality, Customer Satisfaction, and Profitability in the Taiwanese Banking Industry. International Journal of Management. 22 (4) : 635-648.

Li, C., S. (2013). Exploring the Relationship among Service Quality, Customer Loyalty, and Word of Mouth for Privare Higher Education in Taiwan. Asia Pacific Management Review, 18 (4): 375-389.

Lovelock, C. (2002). Service Marketing In Asia. Singapore: Prentice Hall Inc .

Molinari, L.K., Abbart, R., \& Dion, P. (2008). Satisfaction, Quality and Value Effects on Repurchase and Positive Word of Mouth Behavioral Intentions in a B2B Services Context. Journal of Services Marketing, 22 (5): 363-373.

Ng, S., David, M. E., \& Dagger, T. S. (2011). Generating positive word-of-mouth in the service experience. Managing Service Quality: An International Journal, 21(2), 133151.

Parasuraman, A., Zeithaml, V.A. \& Berry, L.L. (1985). A conceptual model of service quality and its implications for future research. Journal of Marketing, 49 (3): 41-50.

Parasuraman, Valarie A. Z. \& Berry. (2002). Delivering Service Quality. New York: Mc Milan.

Qin, Hong. (2009). Links among Perceived Service Quality, Patient Satisfaction, and Behavioral Intension in the Urgent Care Industry: Empirical Evidence from College Students. Doctoral Dissertation at University of North Texas.

Ranaweera, C. \& Prabhu, J. (2003). Palgrave Macmillan on the Relative Importance of Customer Satisfaction and Trust as Determinants of customer Retention and Positive Word of Mouth. Journal of Targeting, Measurement, and Analysis for Marketing, 12(1): 82-90. 
Taylor, Steven; C., Kelvin; Goodwin, S. (2004). The Importance of Brand Equity to Customer Loyalty (in heavy equipment manufacture). The Journal of Product and Brand Management, 13. 4/5: 217 - 227.

JURNAL

MANAJEMEN

INDONESIA

Vol.18 No.1

April 2018
Wen, Chao; Qin, Hong; Prybutok, Victor R.; Blankson, Charles. (2012). The Role of National Culture on Relationship between Customer's Perception of Quality, Values, Satisfaction, and Behavioral Intentions The Quality Management Journal, 19.4: 7 - 23.

$\mathrm{Wu}$, Kung Wen. (2006). Service Quality, Customer Satisfaction, and Customer Loyalty in Customer Electronics E-Tailer: A Structural Equation Modeling Approach. Lynn University. Doctoral Dissertation.

Zeithaml, V. A. and Bitner, M. Jo.(2002). Service Marketing. New York: McGraw Hill. 